\title{
Diferença e educação: pensando essa composição
}

https://doi.org/10.34112/2317-0972a2018v36n73p9-10

\section{Marcus Pereira Novaes ${ }^{1}$}

Davina Marques ${ }^{2}$

Esta EDiÇão da LeITURA: TEORIA \& PRÁTICA se organiza no momento em que a Associação de Leitura do Brasil se renova em uma nova diretoria. Como resultado desse movimento, a Coordenação do periódico passará, na próxima edição, aos membros recém-eleitos: Anderson Trevisan e Renata Aliaga.

Nos últimos anos, o periódico se reorganizou e esta edição mostra parte dessa reestruturação, uma linha editorial mais aberta, que pensa e divulga a leitura em formas mais amplas, em múltiplas linguagens, trazendo elementos para pensar a pesquisa na área, nossas práticas e outros muitos caminhos possíveis no enfrentamento dos enormes desafios que o nosso País nos oferece a cada dia. Parte dos artigos nos leva a essa arena.

Além disso, trazemos, neste número, o dossiê "Diferença, cinema e educação: o que há de pergunta nesta composição?”, organizado pelos professores Dra. Anelice Ribetto (UERJ) e Dr. Valter Filé (UFRRJ e UFF) e que contém textos que nos mobilizam às potentes possibilidades de leitura que dizem respeito à educação e o pensamento das diferenças nos estudos fílmicos.

1. Colégio EDUCAP/Universidade Estadual de Campinas, Campinas, SP, Brasil.

2. Instituto Federal de Educação, Ciência e Tecnologia de São Paulo, Hortolândia, SP, Brasil. 
Atualmente o encontro entre educação e cinema tem disparado outras formas de se pensar com as imagens audiovisuais e tem resultado em pesquisas que lidam com essas imagens, na área da educação, para além do entendimento da história ou narrativa fílmica. Isso faz com que a relação daquele que experimenta as imagens e a relação das próprias imagens entre elas possam derivar em outras formas de conhecimento, ampliando modos de leitura e permitindo que a educação possa se debruçar sobre o campo do cinema para também pensar com as diferenças.

As diferenças não são reduzidas à prática de um saber que emoldura um sujeito em uma identidade. As diferenças se conectam com processos modulatórios de alteridade e de encontros com o que ainda não é conhecido, forçando o pensamento a pensar, produzindo algo novo e provocando a percepção de múltiplos olhares para com o mundo através do som, da imagem e da palavra.

Assim, quando a diferença aparece ela provoca deslocamentos de discursos e saberes tanto de maneira extensiva - que, no caso do cinema, percebemos através de imagens-movimento que desvelam corpos atrás de corpos sem que nunca possamos chegar à identidade fixa de um sujeito, propiciando um olhar mais aberto à vida - como também a diferença pode aparecer de maneira intensiva em vínculo com pensamento - quando sons e cores provocam outros efeitos na montagem fílmica e permitem outras formas de sermos educados imageticamente.

Entre diferença, cinema e educação há, sem dúvida, uma possibilidade de aprendizagem em permanente devir, uma composição que busca afetar o leitor, ou telespectador, ao provocá-lo a pensar o impensável e, quem sabe, enunciar-se em uma pergunta ainda sem referência de um local validado, mas em questionamentos que se fazem em modulação, entre acelerações e pausas, tais quais as imagens-audiovisuais e o pensamento.

Boas leituras! 